\title{
More Women Should Study Entrepreneurship
}

\section{Kimberly Eddleston (Northeastern University)}

KEYWORDS: Entrepreneurship, Women, Higher Education.

Women have become a powerful part of the global economy, but many college and university entrepreneurship programs are not attracting them. In this interview with EIX's Kim Eddleston, professors Candida Brush of Babson College and Linda Edelman of Bentley University -- who've co-authored two books on entrepreneurship and women -- discuss what higher education must do to make entrepreneurship education more appealing and accessible to women. They also talk about why more women must acquire the entrepreneurial skills that will serve them well whether or not they start a business.

\section{Read more:}

Advice, Best Practices and Inspiration for Women Entrepreneurs(https://eiexchange.com/women)

Every College Student Should Take a Course in Entrepreneurship (https://eiexchange.com/content/245-every-college-stud ent-should-take-a-course-in-

en?search=every\%20student)

Small Acts of Entrepreneurship Transcend the Business Realm(https://eiexchange.com/content/337-small-acts-o f-entrepreneurship-transcend-the-

bus?search=small\%20acts)

Additional search terms: women, feminism, female founders, women business owners, glass ceiling, sexual discrimination, business schools, business courses, colleges and universities, entrepreneurship courses, entrepreneurship schools, bias, opportunity 